access to the open air and received some green food; it would appear that these conditions were necessary, at least in part, to supply factors such as vitamins $A$ and $D$, riboflavin and vitamin $B_{12}$, which are now available as inexpensive dry concentrates. Although American experience with suitably vitaminized soya-maize diets suggests that these are capable of giving good production under intensive conditions, it is questionable whether the supplemented all-vegetable diets at present practicable in the U.K. would be sufficiently attractive to secure the necessary degree of food intake under the intensive systems now prevalent. There seem to be reasonable grounds for the suggestion that antibiotics could help to overcome this defect in palatability.

\title{
REFERENCES
}

Bell, J. M. (1952). Sci. Agric. 32, 135.

Carpenter, K. J. \& Duckworth, J. (195I). F. agric. Sci. 4I, 297.

Common, R. H. \& Bolton, W. (1942). F. Soc. Chem. Ind., Lond., 61, 153.

Cravens, W. W. (1952). Proceedings of the 1952 Cornell Nutrition Conference for Feed Manufacturers. Ithaca, N.Y.: Cornell University.

Crowther, C. (1939). Rep. Harper-Adams Coll. Pig Feed Sta. no. 2.

Prentice, J. H. (1933a). Rep. agric. Res. Inst. N. Ire. I932-33, p. 23.

Prentice, J. H. (1933b). F. Minist. Agric. N. Ire. 4, 116.

Prentice, J. H., Baskett, R. G. \& Robertson, G. S. (1930). World's Poult. Congr. Iv. London, sect. B, no. 37, p. 224 .

Robinson, K. L., Coey, W. E. \& Burnett, G. S. (1952). F. Sci. Fd Agric. 3, 448.

Robinson, K. L., Coey, W. E. \& Burnett, G. S. (1953). Emp. F. exp. Agric. (In the Press.)

Sheffy, B. E. (1952). Proceedings of the 1952 Cornell Nutrition Conference for Feed Manufacturers. Ithaca, N.Y.: Cornell University.

\section{Economies in Pig and Poultry Feeding}

\section{By J. DuckworTH, Rowett Research Institute, Bucksburn, Aberdeenshire}

In the narrowest sense economy in feeding consists of devising the cheapest rations that still provide the minimum amounts of nutrients needed for particular rates of growth and production.

In a broader sense the feed supplies in a country as a whole and, in an importing country such as this, the world's feed supplies must be considered to see whether economical rations advocated could be used on a wide scale, in terms of the demands they would create for individual feeding-stuffs.

In the widest sense economy in feeding embraces production problems other than those of feed supplies and costs, since an economical feeding system may impose production charges that reduce profit and thus bar acceptance by the farmer. For example, restricted feeding of pigs, although increasing the efficiency of feed conversion, can extend rearing time to the extent that extra labour costs and smaller throughput reduce profits. Similarly, it may pay better on occasion to provide a richer ration for birds housed intensively in order to reduce labour charges and land use, than to use a more economical ration for the same flock widely dispersed on grass range. 
Animal by-products are the materials of choice in many tested rations, but they are scarce and therefore expensive. One reason for it is that supplies of animal by-products, such as dried skim milk, are largely inflexible, being controlled by the demand for the primary product, in this instance butter and cream.

In their studies of economy, nutritionists regard an attack on this position of animal by-products as contributors of important amino-acids, vitamins and minerals as a main task. Some success in finding alternatives from the vegetable kingdom and from industry, particularly the fermentation industry, has been gained but advances, generally speaking, have been limited. American information is extensive only as far as showing how to use soya-bean meal as a protein source with maize, and British information mainly concerns the use of groundnut meal with barley and miller's offals.

This paper is concerned with problems in providing energy, protein and certain B-complex vitamins and its scope is restricted to British conditions. The provision of minerals and fat-soluble vitamins presents few problems in economy and, obviously, it is never economical to neglect adding enough of these substances.

\section{Vitamins}

Poultry. Rations complying with Ministry of Food regulations provide sufficient thiamine, folic acid, nicotinic acid, pantothenic acid, riboflavin and choline for all classes of poultry (Duckworth \& Ellinger, 1949) although special provision of riboflavin becomes necessary when some laying rations are diluted with grain for feeding birds that are laying hatching eggs.

If plant products replace animal by-products most of the B-vitamins will still be provided in sufficient amounts without special supplements. However, a special riboflavin source such as high-quality grass meal (Brown, 1950), yeast or the synthetic vitamin is often necessary, and can be added without great cost.

Such all-plant rations will also lack vitamin $\mathrm{B}_{12}$ and any other postulated animal protein factors. In our experience, with groundnut-supplemented rations, this lack will have no deleterious effect on the laying of table eggs or more than a transitory effect in slowing the growth of the chick if it carries when hatched a normal body reserve of vitamin $\mathrm{B}_{12}$ (Carpenter \& Duckworth, 195 I $a$; Carpenter, Duckworth \& Ellinger, 1954). Vitamin $B_{12}$ is important for maintaining normal hatchability of eggs, but to a less extent under British than under American conditions where large amounts of soya-bean meal are fed, which raise the vitamin $B_{12}$ requirement (Carpenter \& Duckworth, I95 I $b$; Shrimpton, 1953).

Pigs. In British all-plant rations only riboflavin can fall to borderline levels (Carpenter, 1952). Weanling pigs have shown no dietary need for vitamin $B_{12}$ in United Kingdom trials with all-plant rations (Woodman \& Evans, I95I; Evans, 1952). Supplements of vitamin $B_{12}$ improved neither growth nor feed efficiency of growing pigs, and there is some evidence that the bran and grass meal in these rations have a sparing action on vitamin $B_{12}$ requirements (Carpenter, Duckworth \& Lucas, 1953). 
Protein

Poultry. Early workers attached great importance to animal by-products as supplements to cereals for birds on pasture. Later it was found that the mineral content of the by-products was responsible for the benefit (Orr, Moir, Kinross \& Robertson, 1925; Robertson \& Baskett, 1929). Cereals, cereal offals and minerals constituted an adequate ration and the further addition of any type of protein concentrate gave no extra benefit (Prentice, I933). In some circumstances even cereals and minerals alone could form an adequate ration for birds on pasture (Shaw \& Nightall, 195 $\mathrm{r}$ ).

Apparently rations containing II-12\% protein meet the nitrogen needs of birds on pasture, even if the protein is entirely of cereal origin.

Birds housed indoors have a higher requirement, since they depend for protein entirely on the ration. Combinations of cereals, wheat offals and groundnut meal, containing $14 \%$ protein meet the needs of indoor birds but combinations of plant products containing only $I \mathrm{I} \%$ are deficient in protein. However, II $\%$ protein in the ration is close to adequacy for indoor birds when 8 out of the II \% is derived from cereals and the remaining $3 \%$ from fish meal (Carpenter, Duckworth \& Ellinger, 1954).

The inadequacy of cereal-groundnut combinations containing $11 \%$ protein is accounted for by a methionine deficiency, since addition of $0.06 \%$ DL-methionine to these rations raises egg production to normal levels (Carpenter, Duckworth, Ellinger \& Shrimpton, 1953). At current prices for methionine such supplementation is uneconomic.

Raising the protein level in a cereal ration from 12 to $17.5 \%$ with fish meal depressed the hatchability of eggs from birds on range (Black, I953).

Chicks reared on starting rations ( $18 \%$ protein) and growing rations ( $16 \%$ protein) in which all the protein was of plant origin came into lay at the same time and at the same live weight as birds reared on rations containing animal by-products (Carpenter \& Duckworth, 195 I $a$ ), with no impairment of subsequent egg production (Carpenter, Duckworth \& Ellinger, 1954).

Pigs. Rations rich in protein and in animal by-products were recommended before the war. Weaner rations containing as much as $20 \%$ protein were advocated, and the high level of fish meal recommended involved the use of about $50 \mathrm{lb}$. of fish meal to bring a pig from weaning to bacon weight.

Farm trials, growth studies and measurements of nitrogen retention have now shown that mixtures of barley, bran, minerals and grass meal when supplemented with $7 \%$ fish meal, or with $2 \%$ fish meal and $6 \%$ groundnut meal, or with $20 \%$ groundnut meal (Woodman \& Evans, 1948, I95 I), or with 15\% soya-bean meal (Evans, 1952) meet the needs of pigs between weaning and $90 \mathrm{lb}$. live weight. After $90 \mathrm{lb}$. the mixture needs no protein supplement, provided that the total protein content is $12.5 \%$ (Woodman \& Evans, 195 I). Many samples of barley are too low in protein for this level to be reached and small additions of protein are needed (Carpenter, Duckworth \& Lucas, r953).

Replacement of cereals by fodder beet in pig feeding is now advocated because 
of the higher energy yield/acre from it. However, currently recommended balancer meals involve the use of $40-60 \mathrm{lb}$. of animal by-products to bring a pig from weaning to bacon weight (Dunkin \& Cooper, I949--50; Braude \& Mitchell, I949-50; Jespersen \& Hansen, I953; Frens, 1953). A recent report suggests that lower levels of animal by-products in balancer meals for fodder beet would be equally successful (Sim, Browning \& Walsh, I952-3). Comparable economy in the use of animal by-products in balancer meals for potatoes has also been reported from Sutton Bonington (Robinson, 1948-9).

The importance of top-dressing cereal crops to raise the protein content and reduce the demand for protein supplementing has already been reviewed (Duckworth, 1952).

\section{Energy, and feed restriction}

Poultry. Moderate reductions in growth rate by feed restriction only slightly delay the onset of laying, with little or no effect on subsequent egg production, but feed restriction during laying is unprofitable (cf. Temperton \& Dudley, 1944). A ro\% reduction in feed allowances of birds on pasture did not affect egg production (Eyles, r953).

Pigs. Economy in providing energy for pigs is usually thought of in terms of restricted feeding. In Table $I$ are given the results from an experiment in which

Table I. The influence of scale of feeding on the growth of pigs from 64 to $205 \mathrm{lb}$. live weight, and on the efficiency of conversion of total digestible nutrients (T.D.N.) (Ellis \& Zeller, I934)

\begin{tabular}{|c|c|c|c|c|c|}
\hline Scale of feeding & $\begin{array}{l}\text { Total } \\
\text { feed } \\
\text { eaten } \\
\text { (lb.) }\end{array}$ & $\begin{array}{l}\text { Total } \\
\text { T.D.N. } \\
\text { eaten } \\
\text { (lb.) }\end{array}$ & $\begin{array}{c}\text { Mean daily } \\
\text { T.D.N. } \\
\text { eaten } \\
\text { (lb.) }\end{array}$ & $\begin{array}{l}\text { T.D.N. } \\
\text { / } 100 \text { lb. } \\
\text { weight gain } \\
\text { (lb.) }\end{array}$ & $\begin{array}{l}\text { Time taken } \\
\text { from } 64 \text { to } 205 \\
\text { lb. live weight } \\
\text { (days) }\end{array}$ \\
\hline Full-fed & 707 & 527 & $5 \cdot 27$ & 373 & 100 \\
\hline $4 \%$ of live weight & 543 & 404 & $3 \cdot 5^{8}$ & 283 & I 13 \\
\hline $3 \%$ of live weight & 507 & 377 & $2 \cdot 49$ & 263 & I 5 I \\
\hline $2 \%$ of live weight & 485 & 362 & $1.6 \mathrm{I}$ & 260 & 224 \\
\hline
\end{tabular}

four planes of feeding were used from 64 to $205 \mathrm{lb}$. live weight, the carcasses being analysed. The ration consisted of wheat, lucerne-leaf meal, dried skim milk, slaughter-house tankage and minerals (Ellis \& Zeller, 1934).

The values in Table I show how restriction of feed, and total digestible nutrients ('T.D.N.) allowed feed savings at the cost of prolonged rearing. Important savings in feed were made by reducing allowances from full-feed to $4 \%$ of live weight, time being increased by $I_{3}$ days. Further restrictions (to 3 or $2 \%$ ) saved little extra feed and prolonged rearing disproportionately. Reduction of feed allowances from 4 to $3 \%$ of live weight caused a small reduction in body fat; reduction from 3 to $2 \%$ caused a greater decrease. The Ministry of Agriculture's feeding scale (Woodman, 1952) provides feed at the level of $5 \%$ of body-weight from 40 to $80 \mathrm{lb}$., declining gradually to $3.5 \%$ at $200 \mathrm{lb}$. 


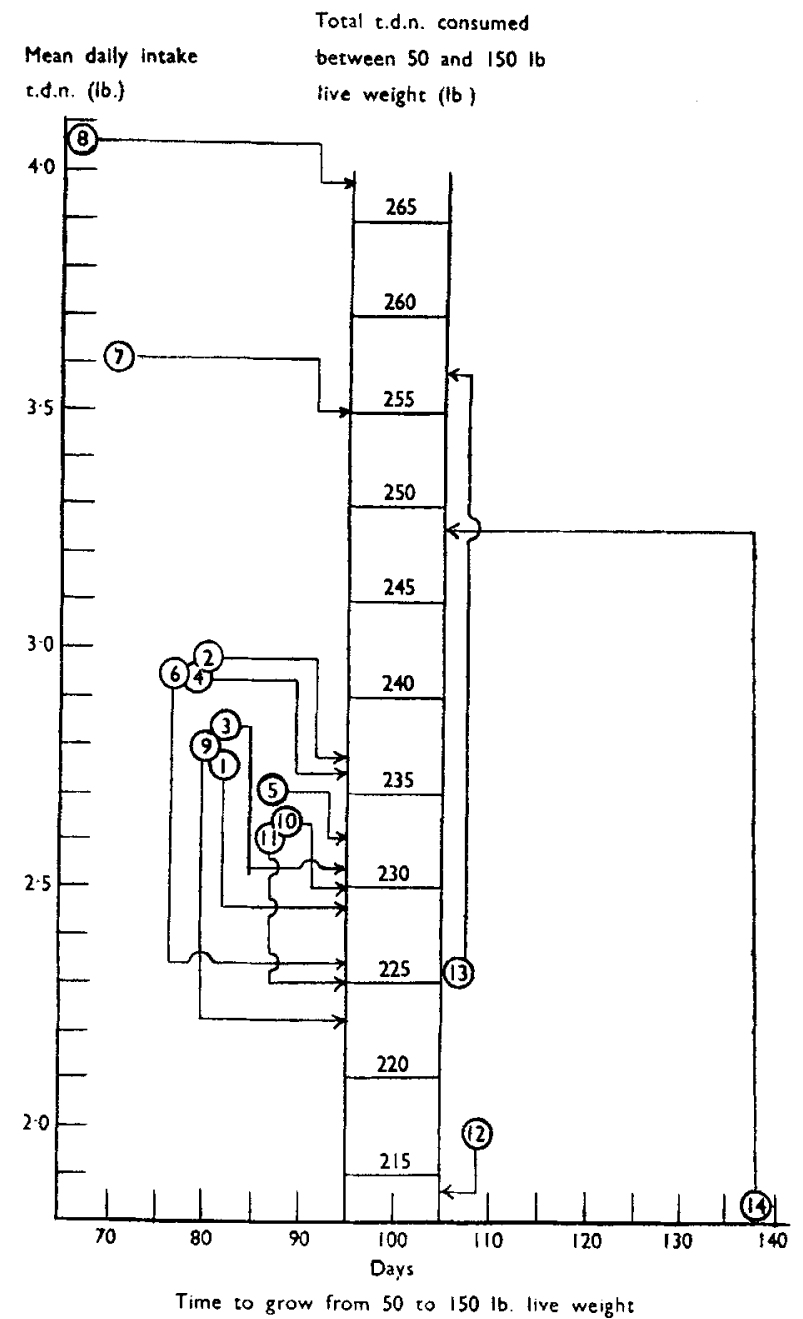

Fig. I. The relation between the mean daily intake of total digestible nutrients (T.D.N.) and time taken to grow from 50 to $\mathrm{r} 50 \mathrm{lb}$. live weight, together with the total consumption of T.D.N. during the period.

Danish data (Jespersen \& Hansen, 1953): I, grain, skim milk and fodder beet ration; 2, grain, skim milk and potato ration; 3 , grain, animal by-products and potato ration; 4, grain and skim milk ration; 5, grain, animal by-products and fodder beet ration; 6, grain and animal by-products ration. American data: 7, (U.S.A.) National Research Council standard (Hughes, Crampton, Ellis \& Loeffel, 1950); 8, Catron, Jensen, Homeyer, Maddock \& Ashton (1952). British data: 9, Woodman \& Evans (1951), Ministry of Agriculture feeding scale; ro, Evans (1952), Ministry of Agriculture feeding scale; II, Carpenter, Duckworth \& Lucas (1953), normal energy ration-normal feeding scale; I2, Carpenter, Duckworth \& Lucas (1953), normal energy ration-restricted feeding scale; 13, Carpenter, Duckworth \& Lucas (1953), low energy ration-normal feeding scale; I4, Carpenter, Duckworth \& Lucas (1953), low energy ration-restricted feeding scale. 
Data from various sources are plotted in Fig. I. As the daily allowance of T.D.N. is reduced, the time to grow from 50 to $150 \mathrm{lb}$. is extended, in agreement with the results of Ellis \& Zeller (1934). Reduction of the daily T.D.N. allowance from 4 to $3 \mathrm{lb}$. prolonged rearing by about $\mathrm{I} 2$ days, with improved T.D.N. conversion efficiency. Further reduction from 3.0 to $2 \cdot 6 \mathrm{lb}$. T.D.N. daily extended rearing time by 8 days, the conversion efficiencies being closely grouped. In this region T.D.N. conversions averaged $230 \mathrm{lb}$./100 $\mathrm{lb}$. gain, with a range of about $\pm 3 \%$, and with no consistent difference between scales of feeding or types of ration. When British rations of normal energy content are fed on restricted scales, and when British low-energy rations are fed on normal or restricted scales the rearing time is prolonged.

Although it is commonly accepted that feed conversions are made more efficiently in Danish than in British pig production this is true only if the comparison is based on total feed weights. Normal Danish rations are higher in energy content than normal British rations. When the rations are compared on an energy (T.D.N.) basis there is no difference.

The data in Fig. I also show that rations of the Woodman-Evans type, low in fish meal, sustain as good growth and T.D.N. conversion as the Danish rations more plentifully supplied with animal by-products.

Some workers have failed to recognize when folding bacon pigs on herbage or feeding them on silage that they are practising restricted feeding. Part, and in some instances all, of the value attributed to the roughage can be accounted for by increased efficiency in the conversion of restricted amounts of a high-energy ration and by slower growth, often to a somewhat lighter finishing weight (see e.g. Baker, 1949; Thompson, 1940).

\section{SUMMARY}

Seventy-five $\%$ of the feed needed by pigs after weaning is eaten between $90 \mathrm{lb}$. live weight and bacon weight. Eighty $\%$ of the feed needed by birds during the first 18 months of life is eaten during the 12 months of laying. All-plant rations, economical in nutrients and price, can be constructed to meet the needs of these classes of stock, without using supplements of the vitamin B complex. Animal byproducts can thus be deflected to the rations of young animals and reproducing stock, again obviating the need for supplements of B-complex vitamins. If economy is made in feeding young stock, vitamin $B_{12}$ is less likely than riboflavin to be deficient.

Protein levels lower than those commonly advocated in the past are satisfactory for growing-fattening pigs and laying birds. Methionine being the limiting aminoacid-at least for laying birds on groundnut-meal rations-cheap sources of this amino-acid would allow further reduction in protein level.

Restricted feeding of pigs, below the Ministry of Agriculture's scale, will save little feed, and only at the expense of prolonged rearing. 
Further economies will depend on a better knowledge of plant products, and particularly on the form that balancer meals for fodder beet and potatoes should take.

\section{REFERENCES}

Baker, F. S. Jr. (1949). Bull. Fla agric. exp. Sta. no. 458.

Black, D. J. G. (1953). Private communication.

Braude, R. \& Mitchell, K. G. (1949-50). Agriculture, Lond., 56, 369.

Brown, W. O. (1950). F. Sci. Fd Agric. r, 219.

Carpenter, K. J. (1952). Int. Congr. Anim. Husb. vi. Copenhagen, 2, 68.

Carpenter, K. J. \& Duckworth, J. (1951a). F. agric. Sci, 41, 297.

Carpenter, K. J. \& Duckworth, J. (195 Ib). World's Poult. Congr. IX. Paris, 2, 18.

Carpenter, K. J., Duckworth, J. \& Ellinger, G. M. (1954). F. agric. Sci. (In the Press.)

Carpenter, K. J., Duckworth, J., Ellinger, G. M. \& Shrimpton, D. H. (I953). Unpublished data.

Carpenter, K. J., Duckworth, J. \& Lucas, I. A. M. (1953). Unpublished data.

Catron, D. V., Jensen, A. H., Homeyer, P. G., Maddock, H. M. \& Ashton, G. C. (r952). F. Anim. Sci. II, 221 .

Duckworth, J. (1952). Chem. E Ind. p. I 139.

Duckworth, J. \& Ellinger, G. M. (1949). Brit. F. Nutr. 3, 253.

Dunkin, A. C. \& Cooper, M. M. (1949-50). Agriculture, Lond., 56, 364.

Ellis, N. R. \& Zeller, J. H. (1934). Bull. U.S. Dep. Agric. no. 413.

Evans, R. E. (1952). Ұ. agric. Sci. 42, 438.

Eyles, D. E. (1953). Private communication.

Frens, A. M. (I953). Private communication.

Hughes, E. H., Crampton, E. W., Ellis, N. R. \& Loeffel, W. J. (1950). Recommended Nutrient Allowances for Domestic Animals. no. 2. Recommended Nutrient Allowances for Swine, revised ed. Washington, D.C.: National Research Council.

Jespersen, J. \& Hansen, V. E. H. (1953). Beretn. forsøgslab. no. 264.

Orr, J. B., Moir, M., Kinross, A. \& Robertson, G. S. (1925). Scot. F. Agric. 8, 263.

Prentice, J. H. (1933). F. Minist. Agric. N. Ire. 4, I16.

Robertson, G. S. \& Baskett, R. G. (I929). F. Minist. Agric. N. Ire. 2, I.

Robinson, H. G. (I948-9). Agriculture, Lond., 55, 423.

Shaw, R. B. \& Nightall, E. W. (195I). World's Poult. Sci. F. 7, 202.

Shrimpton, D. H. (1953). Unpublished data.

Sim, A. H., Browning, D. R. \& Walsh, W. A. (1952-3). Agriculture, Lond., 59, 469.

Temperton, H. \& Dudley, F. J. (1944). Harper Adams Util. Poult. F. 29, 24.

Thompson, J. K. (1940). Kirton agric. F. 6, 2 I.

Woodman, H. E. (1952). Bull. Minist. Agric., Lond., no. 48.

Woodman, H. E. \& Evans, R. E. (1948). F. agric. Sci. 38, 200.

Woodman, H. E. \& Evans, R. E. (I95I). F. agric. Sci. 4I, I02.

\section{The Role of the Nutrition Adviser in Livestock Production}

\section{By A. Eden, Ministry of Agriculture and Fisheries National Agricultural Advisory Service (Eastern Province), Anstey Hall, Trumpington, Cambridge}

To be an efficient and successful adviser on matters of live-stock feeding requires a practical and realistic outlook. The adviser must have a good working knowledge of agricultural practices, especially of animal husbandry, and he should have had a sound training in agricultural chemistry, preferably after taking a degree in pure science. His main duties are to translate into practical terms the fundamental facts of nutritional science, to keep abreast of all new developments and advances in nutrition, and as far as possible to keep the research worker aware of the problems 